\title{
INFLUENCES OF SUBGRID HETEROGENEITY OF LAND USE AND GRID SIZE ON WATER AND HEAT BUDGETS IN THE SHUTOKEN AREA
}

\author{
Yangwen JIA ${ }^{1}$, Nobuyuki TAMAI ${ }^{2}$ and Norio TANAKA ${ }^{3}$ \\ 1 Ph.D., Dept. of Information, INA Construction, Ltd. (Sekiguchi 1-44-10, Bunkyo-ku, Tokyo 112, Japan) \\ 2 Professor, Dept. of Civil Eng., University of Tokyo (Hongo 7-3-1, Bunkyo-ku, Tokyo 113, Japan) \\ 3 Ph.D., Dept. of Information, INA Construction, Ltd. (Sekiguchi 1-44-10, Bunkyo-ku, Tokyo 112, Japan)
}

\begin{abstract}
Water and heat budgets in 1993 in the Shutoken Area of about $7800 \mathrm{~km}^{2}$ are studied by using a distributed model. The land use data and DEM are based on the Saimitsu Suuchi Joho of Japan Geography Institute. The meteorological data are based on the 46 AMeDAS stations in the area. In addition to the analysis of annual budgets, the comparison of seasonal evapotranspiration is also conducted.

Influences of grid size are shown by comparison of simulation result by a grid size of $1 \mathrm{~km}$ and that by $5 \mathrm{~km}$. Influences of subgrid heterogeneity of land use are shown by comparison of simulation result of uniform land use scheme with that of mosaic land use scheme. It is found that subgrid heterogeneity of land use gives stronger influence on annual water and heat budgets in urbanized area than grid size does.
\end{abstract}

Key Words: Water budget, heat budget, distributed model, urbanization, subgrid heterogeneity, scale problem

\section{INTRODUCTION}

With the further development of distributed hydrological models, they are expected to apply efficiently to mesoscale or largescale problems. In this paper, a distributed model ${ }^{1)}$ is applied to study the distributions of water and heat budgets in 1993 in the Shutoken Area in a time step of 1 hour and in two grid sizes of $1 \mathrm{~km}$ and $5 \mathrm{~km}$. The land use data and DEM are based on the Saimitsu Suuchi Joho of Japan Geography Institute. The meteorological data are based on the 46 AMeDAS stations in the area.

The subgrid heterogeneity problem draws attentions of both hydrologists and meteorologists in recent years. It includes both the heterogeneity of land cover and that of atmosphere forcing inside a grid cell. In this paper, a mosaic method ${ }^{2)}$ is adopted to consider the subgrid heterogeneity of land use and compared with the traditional uniform land use scheme.

\section{MODEL DESCRIPTION}

The details of the distributed model are suggested to refer to the reference. The diagram of model structure inside a grid cell is shown in Fig.1. A brief description of the model is given as follows. The vertical structure of the model has 8 layers, namely an interception layer, a depression layer, 3 unsaturated soil layers, a transition layer, an unconfined aquifer and a confined aquifcr. To reflect subgrid heterogeneity of land use because of quite big a grid size, the land use inside every grid is classified into 3 groups, namely a water body group, a soil-vegetation group and an impervious group. The soil-vegetation group is further classified into of bare soil, short vegetation and tall vegetation. The water and heat budgets of each group are analyzed respectively and the area average is conducted to obtain the averaged budgets in a whole grid. The Penman-Monteith equation is adopted to calculate evapotranspiration and the aerodynamic method to obtain sensible heat flux. Surface temperature is solved by the Force-Restore method. Infiltration excess during heavy rains is calculated by using a generalized Green-Ampt model ${ }^{3)}$. Saturation excess 
during the other periods is obtained by balance analysis in unsaturated soil layers. The distributed model has been verified in the Catchment of Tama River, Tokyo Metropolitan.

By adopting this kind of model structure, the subgrid heterogeneity of land cover is reflected. Land cover determines parameters of both the heat budges on the surface and the water movement under the surface, therefore it has important influences on water and heat budgets. Though the meteorological forcing and groundwater parameters also have subgrid heterogeneity, they are treated as be homogenous inside a grid cell for simplification in this study.

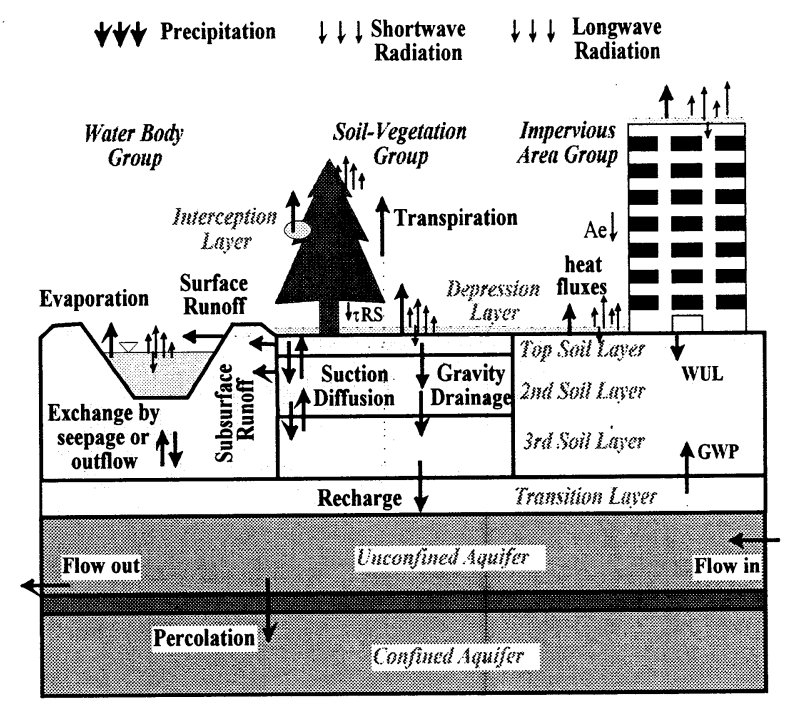

Fig.1 Diagram of model structure inside a grid cell.

In this study, emphasis is laid on water and heat budgets near land surfaces (including unsaturated soil layers). Thus, groundwater flow simulation and river flow routing are not conducted in this study. In this way, the water balance equation can be simplified as Eq. (1):

$$
P=E+R+I
$$

Where $\mathrm{P}$ is the precipitation, $\mathrm{E}$ the evapotranspiration, $\mathrm{R}$ the runoff and $\mathrm{I}$ the infiltration.

The heat balance equation is shown as Eq. (2):

$$
\mathrm{RN}+\mathrm{Ae}=\mathrm{lE}+\mathrm{H}+\mathrm{G}
$$

Where $\mathrm{RN}$ is the net radiation, $\mathrm{Ae}$ is the anthropogenic source, IE the latent heat flux, $\mathrm{H}$ the sensible heat flux and $G$ the heat conduction into soil

\section{APPLICATION}

\section{(1) Data input}

The land use and topography are based on the Saimitsu Suuchi Joho of Japan Geography Institute, which is renewed once five years. The land use in 1989 and topography are shown in Fig.2 by a grid resolution of $100 \mathrm{~m}$ by $100 \mathrm{~m}$. They are the newest available data and are used in this study. As mentioned above, grid cell size of $1 \mathrm{~km}$ and $5 \mathrm{~km}$ are used for simulation, mosaic land use is considered in every grid cell while the elevation is treated by average method.

The meteorological data, i.e., hourly precipitation, wind velocity, sunshine hours and air temperature are based on the 46 AMeDAS stations in the area (see Fig.2). The nearest station is used to provide meteorological data for every grid cell.

Four kinds of soils are considered in top soil layer, which are Kantoloam, lowland soil, forest soil and urbanized Kantoloam. Soil parameters are referred to Herath et al. ${ }^{4)}$ etc.

In addition, anthropogenic energy consumption is related to land use and it is referred to Kawamata ${ }^{5}$. Vegetation parameters are species dependent and referred to Wilson et al. ${ }^{6}$ etc.

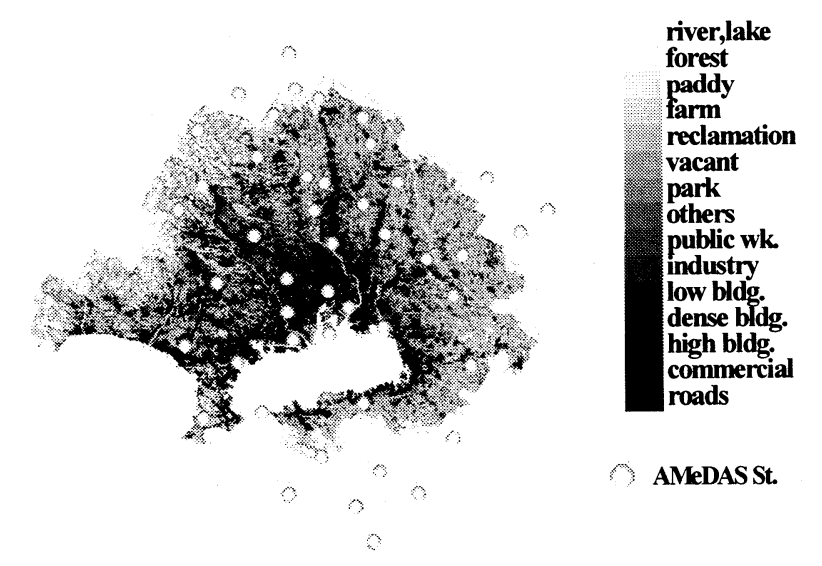

Fig.2 Land use, topography, and AMeDAS stations in the Shutoken Area.

\section{(2) Result by a grid size of $1 \mathrm{~km}$}

The annual water and heat balances in 1993 in the whole area are shown in Table 1. From the results it can be seen that the runoff coefficient is about 0.3 in the Shutoken Area.

The distributions of annual water and heat budgets are shown in Fig.3 and Fig.4 (textured on the topography). It can bee seen that the budgets have large variations, e.g., the annual evapotranspiration ranges from 300 to $900 \mathrm{~mm}$ and the sensible heat flux from -135 to $1800 \mathrm{MJ} / \mathrm{m}^{2}$. The impacts of urbanization can be seen clearly from the 
obvious differences between the central Tokyo and outside areas.

\section{(a) Evapotranspiration}
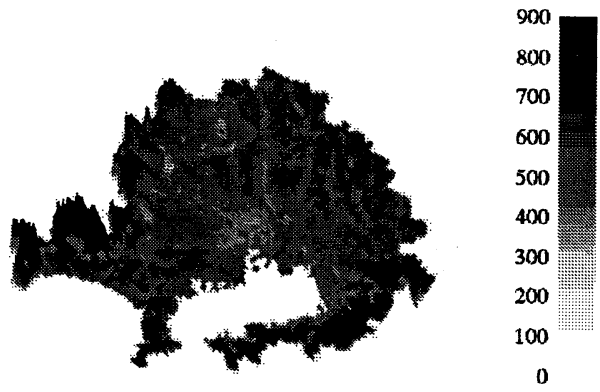

(b) Infiltration
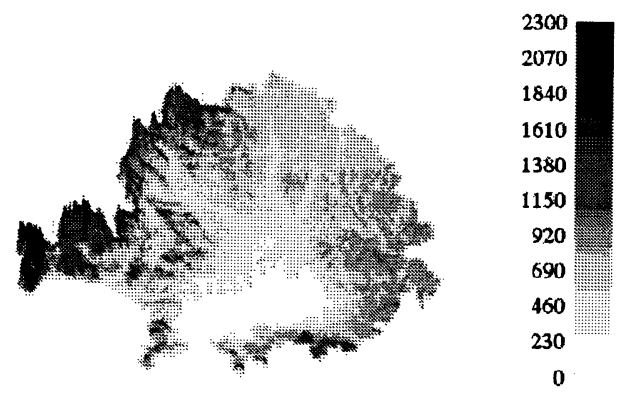

(c) Surface Runoff

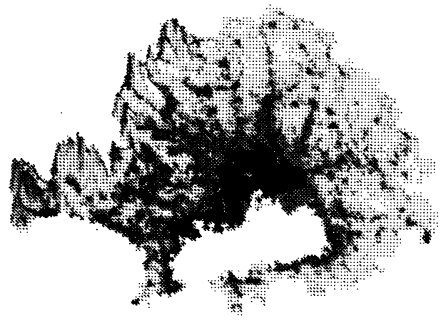

1500
1350
1200
1050
900
750
600
450
300
150
0

Fig. 3 Distributions of annual water budgets in 1993 in the Shutoken Area. (Unit: mm/year)

Table 1 Annual water and heat balances in 1993 in the Shutoken Area.

\begin{tabular}{|c|r|r|r|r|r|}
\hline $\begin{array}{c}\text { Water balance } \\
(\mathrm{mm} / \text { year })\end{array}$ & $\mathrm{P}$ & $\mathrm{E}$ & $\mathrm{R}$ & & $\mathrm{I}$ \\
\cline { 2 - 6 } & 1629 & 568 & 473 & & 589 \\
\hline \multirow{2}{*}{$\begin{array}{c}\text { Heat balance } \\
\left(\mathrm{MJ} / \mathrm{m}^{2} / \text { year }\right)\end{array}$} & $\mathrm{RN}$ & $\mathrm{Ae}$ & $\mathrm{IE}$ & $\mathrm{H}$ & $\mathrm{G}$ \\
\cline { 2 - 6 } & 1711 & 189 & 1395 & 500 & 5 \\
\hline
\end{tabular}

(a) Net Radiation

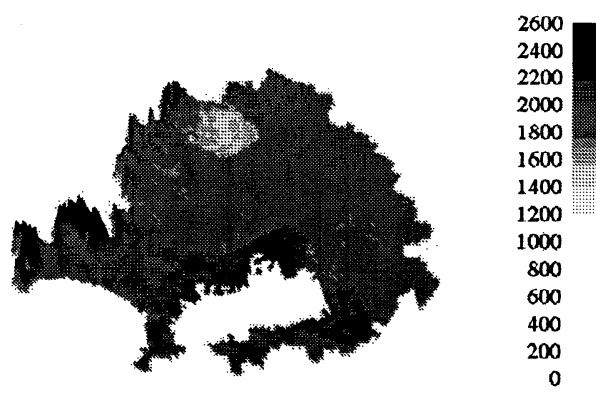

(b) Latent Heat
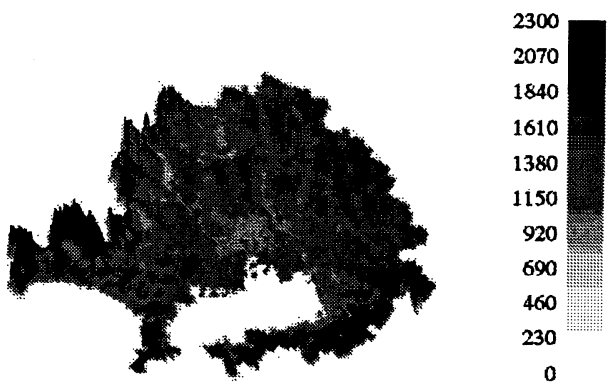

\section{(c) Sensible Heat}

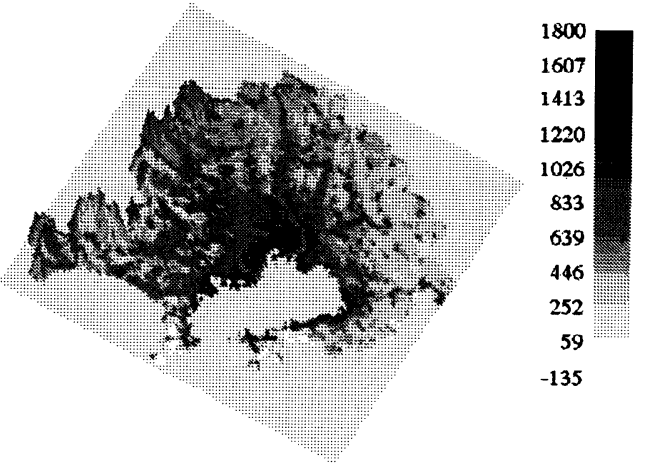

Fig. 4 Distributions of annual heat budgets in 1993 in the Shutoken Area. (Unit: $\mathrm{MJ} / \mathrm{m}^{2} /$ year)

The comparison of seasonal evapotranspiration distributions is shown in Fig.5. It can be seen that the evapotranspiration in winter (maximum 1.5 $\mathrm{mm} /$ day) is quite different from those in other seasons while the differences in spring, summer and autumn are not so obvious. The simulation also gives that the averaged evapotranspirations are 1.47 $\mathrm{mm}$ /day in spring, $2.08 \mathrm{~mm} /$ day in summer, 1.91 $\mathrm{mm} /$ day in autumn and $0.75 \mathrm{~mm} /$ day in winter in the Shutoken Area respectively. 
(a) Spring

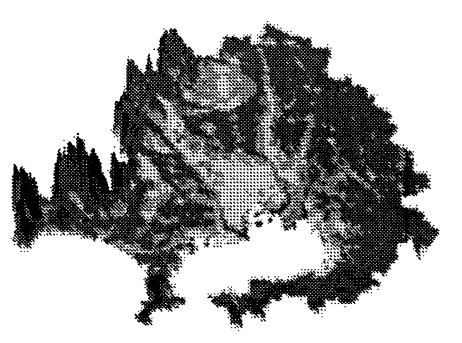

(b) Summer

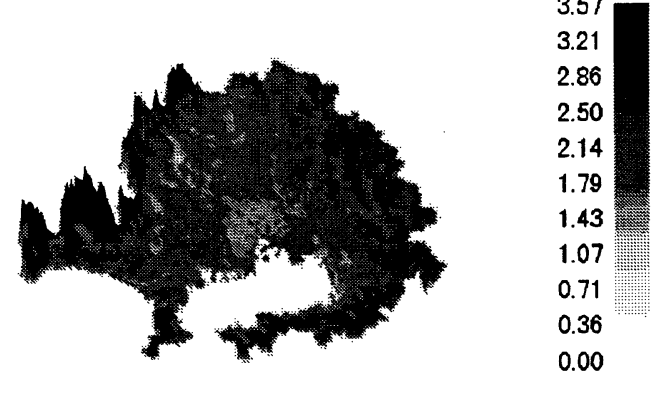

(c) Autumn

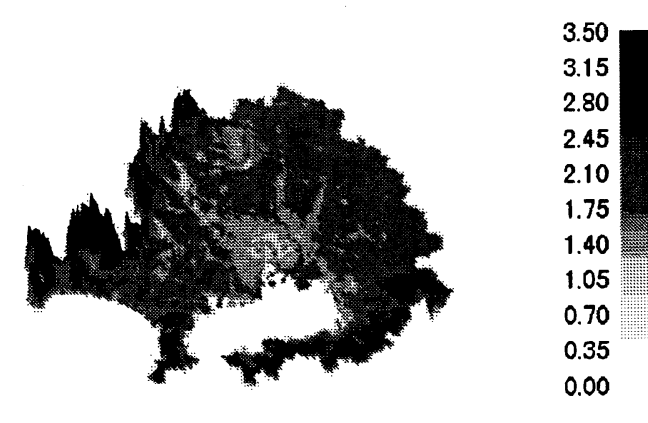

(d) Winter

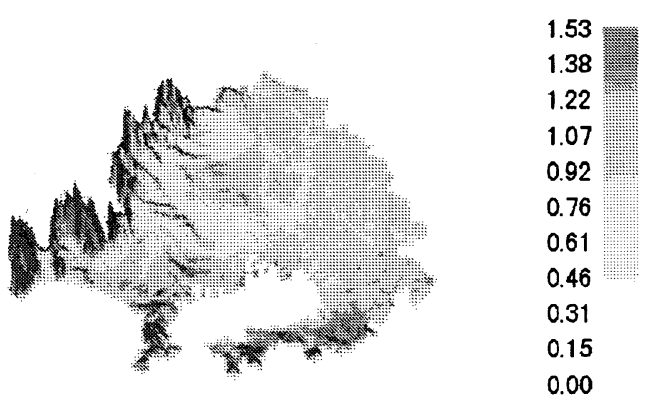

Fig. 5 Comparison of seasonal evapotranspiration in 1993 in the Shutoken Area. (Unit: $\mathrm{mm} /$ day)

\section{INFLUENCES OF GRID SIZE AND SUBGRID HETEROGENEITY OF LAND USE}

Influences of grid size and those of subgrid heterogeneity of land use are described especially in this section. Influences of grid size are studied by changing the grid size from $1 \mathrm{~km}$ to $5 \mathrm{~km}$ with the model structure kept unchanged. Influences of subgrid heterogeneity of land use are conducted by comparing the simulation results of mosaic land use scheme with those of uniform land use scheme. Here, the mosaic land use scheme means the model structure adopted in Fig.1, whereas the uniform land use scheme means to represent a grid cell by using the dominant land use which has a maximum area percentage. In the case of the uniform land use scheme, all parameters of the grid cell, e.g., the soil parameters and surface parameters such as permeability, albedo and roughness height etc. are represented by those of the dominant land use.

\section{(1) Grid size}

Comparisons of simulation result by a grid size of $1 \mathrm{~km}$ and that by $5 \mathrm{~km}$ (both by mosaic land use scheme) are shown in Table 2 and Table 3. The difference of water budgets ranges from $0.2 \%$ to $4.9 \%$ and that of heat budgets from 0 to $1.1 \%$.

Table 2 Comparison of annual water budgets. ( $\mathrm{mm} / \mathrm{year}$ )

\begin{tabular}{|c|r|r|r|r|}
\hline Grid size & $\mathrm{P}$ & $\mathrm{E}$ & $\mathrm{R}$ & $\mathrm{I}$ \\
\hline $1 \mathrm{~km}$ & 1629 & 568 & 473 & 589 \\
\hline $5 \mathrm{~km}$ & 1602 & 569 & 464 & 570 \\
\hline difference & $1.7 \%$ & $0.2 \%$ & $1.9 \%$ & $4.9 \%$ \\
\hline
\end{tabular}

Table 3 Comparison of annual heat budgets. (MJ/m²/year)

\begin{tabular}{|c|r|r|r|r|r|}
\hline Grid size & $\mathrm{RN}$ & $\mathrm{Ae}$ & $\mathrm{IE}$ & $\mathrm{H}$ & $\mathrm{G}$ \\
\hline $1 \mathrm{~km}$ & 1711 & 189 & 1395 & 500 & 5 \\
\hline $5 \mathrm{~km}$ & 1713 & 187 & 1398 & 498 & 5 \\
\hline difference & $0.1 \%$ & $1.1 \%$ & $0.2 \%$ & $0.4 \%$ & 0 \\
\hline
\end{tabular}

\section{(2) Subgrid land use heterogeneity}

Comparisons of simulation result of uniform land use scheme with that of mosaic land use scheme by a grid size of $1 \mathrm{~km}$ are shown in Table 4 and Table 5, whereas those by a grid size of $5 \mathrm{~km}$ shown in Table 6 and Table 7. From these tables we can see the differences caused by neglecting subgrid heterogeneity of land use are generally much bigger than the influence of grid size. For example, the difference of annual runoff between uniform land use scheme and mosaic land use scheme by a grid size of $1 \mathrm{~km}$ is $12.3 \%$ which is much bigger than the difference $1.9 \%$ between $1 \mathrm{~km}$ 
mosaic land use scheme and $5 \mathrm{~km}$ mosaic land use scheme. In addition, the computation time by a grid size of $5 \mathrm{~km}$ is about $1 / 25$ times of that by $1 \mathrm{~km}$. This means that consideration of subgrid heterogeneity of land use can shorten computation time by adopting a coarser grid cell without much reduction of computation accuracy.

Comparison of distributions of water and heat budgets by a grid size of $1 \mathrm{~km}$ between mosaic land use scheme and uniform land use scheme are shown in Fig.6 and Fig.7. From these figures it can be seen that the difference of distributions is also quite obvious. The mosaic scheme gives more gradual and continuous spatial variations of water and heat budgets than the uniform land use scheme.

(a) Evapotranspiration
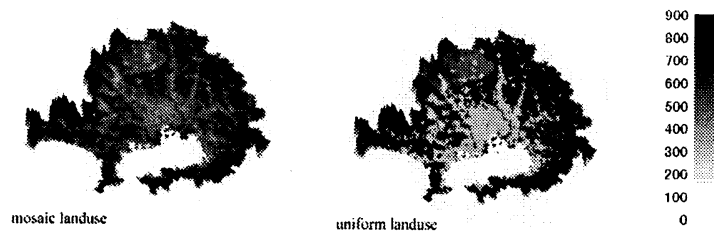

(b) Infiltration
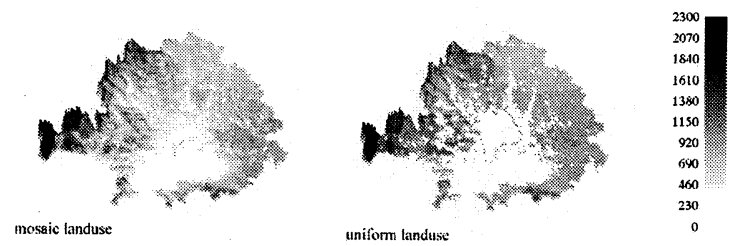

(c) Surface Runoff
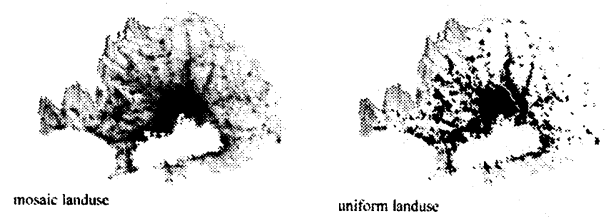

Table 6 Comparison of annual water budgets by a grid size of $5 \mathrm{~km}$.

\begin{tabular}{|c|r|r|r|r|}
\hline scheme & $\mathrm{P}$ & $\mathrm{E}$ & $\mathrm{R}$ & $\mathrm{I}$ \\
\hline Mosaic landuse & 1603 & 569 & 464 & 570 \\
\hline Uniform landuse & 1603 & 594 & 377 & 631 \\
\hline difference & 0 & $4.4 \%$ & $18.8 \%$ & $10.7 \%$ \\
\hline
\end{tabular}

Table 7 Comparison of annual heat budgets by a grid size of $5 \mathrm{~km}$. $\left(\mathrm{MJ} / \mathrm{m}^{2} /\right.$ year $)$

\begin{tabular}{|c|r|r|r|r|r|}
\hline Grid size & RN & Ae & lE & H & G \\
\hline Mosaic landuse & 1713 & 187 & 1398 & 498 & 5 \\
\hline Uniform landuse & 1780 & 160 & 1461 & 474 & 5 \\
\hline difference & $3.9 \%$ & $14.4 \%$ & $4.5 \%$ & $4.8 \%$ & 0 \\
\hline
\end{tabular}

(a) Net Radiation
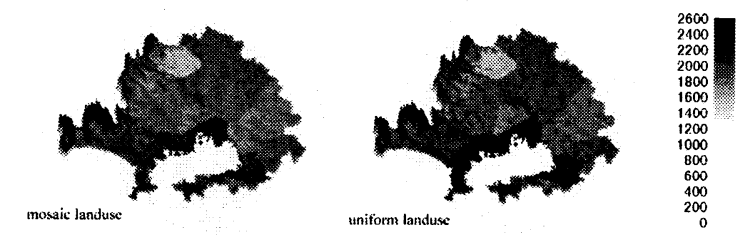

(b) Latent Heat
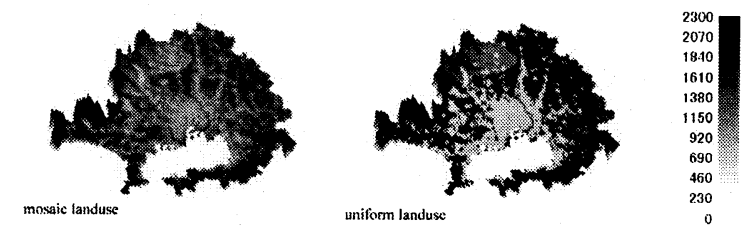

(c) Sensible Heat
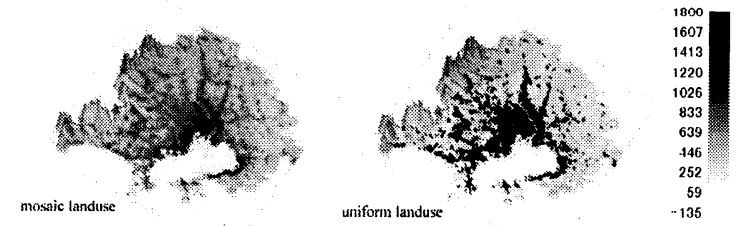

Fig. 7 Comparison of distributions of annual heat budgets by a grid size of $1 \mathrm{~km}$. (Unit: $\mathrm{MJ} / \mathrm{m}^{2} /$ year)

From above results it can be seen that land cover has big influence on water and heat budgets in urbanized region and it is important to correctly represent land cover ratio of each type in simulation. This is because that the difference land cover has a distinctive characteristic in urbanized region. For example, the hydrological and heat processes in the urban cover and grassland are very different, especially evaporation, surface runoff and heat fluxes. The uniform land use scheme will overlook this difference by using a dominant land use to represent a whole grid cell.

Though the model adopted in this study had been duely verified before in the study ${ }^{3)}$ for the 
Middle Tama River and the Tokyo Metropolis by using the observations in the Ishihara discharge station, the wastewater treatment plants and the Tokyo Tower, the further verification is expected in future.

\section{CONCLUSION}

The distributed model (Jia and Tamai, 1998) is further tested through its application to a mesoscale area, the Shutoken Area with reasonable results. Influences of grid size are shown by comparison of simulation result by a grid size of $1 \mathrm{~km}$ and that by $5 \mathrm{~km}$. Influences of subgrid heterogeneity of land use are shown by comparison of a simulation result of uniform land use scheme with that of mosaic land use scheme. It is found that subgrid heterogeneity of land use gives stronger influences on annual water and heat budgets in urbanized area than grid size does. An efficient simulation of averaged water and heat budgets in largescale areas through a coarser grid cell can be realized without much lowering of accuracy if subgrid heterogeneity of land use is considered in a distributed model.

ACKNOWLEDGMENT: This study is partly supported by Strategic Basic Research of Monbusho
(Principal researcher, Prof. Sadakata).

\section{REFERENCES}

1) Jia, Y. and Tamai, N.: Modeling infiltration into a multilayered soil during an unsteady rain, Ann. J. Hydraul. Eng., JSCE, Vol.41, pp.31-36, 1997.

2) Avissar, R. and Pielke, R.A.: A parameterization of heterogeneous land-surface for atmospheric numerical models and its impact on regional meteorology, Mon. Wea. Rev., 117, pp.2113-2136, 1989.

3) Jia, Y. and Tamai, N.: Integrated analysis of water and heat balances in Tokyo metropolis with a distributed model, $J$. Japan Soc. Hydrol. \& Water Resour., Vo11. No.2, pp.150163, 1998.

4) Herath, A. K., Mushiake, K. and Hironaka, S.: Field estimation of saturated conductivity using borehole test: influence of unsaturated flow and soil anisotropy, Ann. J. Hydraul. Eng., JSCE, Vol.36, pp.435-440, 1992.

5) Kawamata, K.: Development of a 3-D Urban Climate Model for an Analysis of Thermal Environment (in Japanese), Master Degree thesis submitted to the University of Tokyo, 80 p., 1994.

6) Wilson, M. F., Henderson-Sellers, A, Dickinson, R. E. and Kennedy, P.J.: Sensitivity of the biosphere - atmosphere transfer scheme (BATS) to the inclusion of variable soil characteristics, J. Climate Appl. Meteorol., Vol.26, pp.341$362,1987$.

(Received September 30,1998) 